\title{
Effect of heating and glycation on the allergenicity of Ara h 2/6
}

\author{
Fany Blanc ${ }^{1}, Y_{v}$ vonne Vissers ${ }^{2 *}$, Per Stahl Skov ${ }^{3}$, Phil Johnson ${ }^{4}$, Clare Mills $^{4}$, Harry Wichers $^{2}$, Karine Adel-Patient ${ }^{1}$ \\ From Food Allergy and Anaphylaxis Meeting 2011 \\ Venice, Italy. 17-19 February 2011
}

\begin{abstract}
Aim
To study the effect of heating and glycation on the IgEbinding properties and biological activity of $2 \mathrm{~S}$ albumins (Ara h 2/6) from peanut.
\end{abstract}

\section{Methods}

Native Ara h 2/6 was purified from raw peanuts and heated in solution $\left(15 \mathrm{~min}, 110^{\circ} \mathrm{C}\right)$ in either the presence or absence of glucose, or purified from roasted peanut. Using PBMC and sera from peanut allergic patients the cellular proliferative potency, IgE reactivity (reverse EAST inhibition) and functionality (basophils activation) of allergens were assessed.

\section{Results}

Heating Ara h $2 / 6$ at $110^{\circ} \mathrm{C}$ resulted in extensive denaturation whilst Ara h 2/6 extracted from roasted peanut retained its native conformation. Allergen stimulation of PBMC from peanut allergic patients induced proliferation of mainly CD4+ T-cells and induction of Th2 cytokine secretion which was unaffected by thermal processing. IgE reactivity and functionality of Ara $h$ 2/6 was decreased by heating. Whilst heating-glycation further reduced the IgE binding capacity of the proteins, it moderated their loss of histamine releasing capacity. Ara $\mathrm{h} 2 / 6$ purified from roasted peanut demonstrated the same IgE reactivity as unheated, native Ara h 2/6.

\section{Conclusion}

Although no effect of processing on T-cell reactivity was observed, heat induced denaturation and reduced the IgE reactivity and functionality of Ara h 2/6; Ara h 2 and 6 purified from roasted peanut retained the structure and IgE reactivity of the native protein. This study

\footnotetext{
${ }^{2}$ Wageningen University, Cell Biology and Immunology, Wageningen, Netherlands

Full list of author information is available at the end of the article
}

further demonstrates the effect of thermal treatment on the allergenicity of peanut allergens.

\section{Acknowledgements \\ This work was performed within EuroPrevall EU-funded project.}

\section{Author details}

${ }^{1}$ INRA, Unite d'Immuno-Allergie Alimentaire, Jouy-en-Josas, France. ${ }^{2}$ Wageningen University, Cell Biology and Immunology, Wageningen, Netherlands. ${ }^{3}$ RefLab ApS, Copenhagen, Denmark. ${ }^{4}$ Institute of Food Research, Norwich, UK

Published: 12 August 2011

\section{doi:10.1186/2045-7022-1-S1-013}

Cite this article as: Blanc et al:: Effect of heating and glycation on the allergenicity of Ara h 2/6. Clinical and Translational Allergy 2011 1(Suppl 1): 013.
Submit your next manuscript to BioMed Central and take full advantage of:

- Convenient online submission

- Thorough peer review

- No space constraints or color figure charges

- Immediate publication on acceptance

- Inclusion in PubMed, CAS, Scopus and Google Scholar

- Research which is freely available for redistribution

Submit your manuscript at www.biomedcentral.com/submit

\section{() Biomed Central}

\section{Biomed Central}

(c) 2011 Blanc et al; licensee BioMed Central Ltd. This is an open access article distributed under the terms of the Creative Commons Attribution License (http://creativecommons.org/licenses/by/2.0), which permits unrestricted use, distribution, and reproduction in any medium, provided the original work is properly cited. 